\title{
Image management and competitive advantage of manufacturing firms in South-East, Nigeria
}

\author{
Madueke, Daniel C. \\ Ezenwakwelu, Charity A. \\ Department of Management \\ University of Nigeria \\ Nwanmuoh, Emmanuel E. \\ Department of Marketing \\ University of Nigeria
}

\section{Keywords}

Image Management, Competitive advantage, product Differentiation, Public Trust, Reputation and Social responsibility

\begin{abstract}
The key to acquire a favourable image and reputation is the management of an organisation's identity. The study examined the effect of corporate social responsibility on organisations' productivity, it also sought to ascertain the effect of corporate reputation on organisations' growth, as well as assess the effect of product differentiation on strategic advantage. The study adopted the survey research design which was conducted through the administration of a structured questionnaire designed on a five-point Likert scale format for ten selected manufacturing firms in South East, Nigeria. The sample size of 563 was derived from the population of 9038 employees of junior and senior category of the manufacturing firms. Findings from the logistic regression revealed that corporate social responsibility positively affected organizations' productivity; corporate reputation had a positive effect on organisations' growth; and product differentiation positively affected strategic advantage. The study affirmed that corporate image management is an essential key for obtaining and maintaining public trust. And that manufacturing firms in Nigeria should carry out corporate social responsibility to gain public trust and better image, which in the long run will increase patronage and profitability.
\end{abstract}

Corresponding author: Ezenwakwelu, Charity A

Email addresses for the corresponding author: charityezenwa80@yahoo.com

First submission received: $13^{\text {th }}$ August 2019

Revised submission received: $28^{\text {th }}$ November 2019

Accepted: 27th December 2019

\section{Introduction}

Corporate image can be traced back to the era of the evolution of the theory relating to corporate identity management since the 1950s (Balmer, 1998). Essentially, corporate image can be explained as the general notion consumers create as a result of accumulated feelings and involvement with an organisation which are stored in memory, transformed into a positive or negative meaning and recalled when the name of the organisation is mentioned (Hatch, Schultz, \&Williamson, 2003). The key to acquire a favourable image and reputation is the management of an organisation's identity and this explains the importance of corporate image and its management. It has been recognized that images have direct and clear links with money, value, and profitability (Christensen \& Askegaard, 2001). No company can ignore corporate image since every organisation has an image (Bernstein, 2008). Whether the image is created consciously or unconsciously, it affects the behaviour of people, hence, knowledge of the corporate image helps managers direct their communication effort in a more efficient way (Bernstein, 2008). Corporate image is the eye of the receiver. It is simply the picture that an audience has of an organisation through the accumulation of all received messages. It is determined by all the company's actions. Corporate image is the combined impact made on the mind of an observer by all of a corporation's planned and unplanned visual and verbal communications as well as by outside influences (Gregory \& Wiechman, 2010). When a 
customer regards a company as a good community player, with honorable stakeholders, an innovator or added value creator, then your outgrowth is trusted, you have achieved a successive level of image (Gregory \& Wiechman, 2010).

In today's competitive environment, there is a competitive pressure and the desire to be recognised and supported; corporations invest millions every year to strengthen their corporate images and reputations. Led by the best strategic thinking on the matter, business managers select those attributes of the organisation that is unique, authentic, and non-imitable, and look for alluring ways to project this image to the outside world as into the hearts and minds of their own employees (Hatch and Schultz 2004). Nowadays also, the notions of images, identities, and brands are gaining renewed attention among scholars and managers (Olins, 2005). It is more and more difficult to gain competitive advantage nowadays when products and services are becoming more similar. In those circumstances' companies, wanting to gain it, must utilize intangibles such as corporate identity, corporate branding, corporate image and corporate reputation (Balmer and Greyser, 2003). From a practitioners' point of view, as products and competitors proliferate, the most repeated names and images will dominate (Melewar and Saunders, 2000).

Again, corporate image is the sum of expectations and impressions stakeholders have built up in their minds. The visual design of outputs is only one of several factors contributing to an organization's corporate image. Corporate identity is mainly under the control of the host organisation, corporate image, on the other hand, is formed within the minds of target audiences as a result of different received messages. Images can only be influenced by host organisations; it is exceedingly difficult to control of focus an image (Tomalin, 2003). Corporate image is a good competitive advantage tool used by organisations to achieve set out goals. Competitive advantage according to Porter (1996) is the ability of a company to achieve economic benefits in respect to the profits that can be achieved by a competitor in the market in the same industry. Companies that have a competitive advantage always had the ability to understand the changes in the structure of the market and is able to choose an effective marketing strategy. The corporate image is very important as it determines the success of an organization (Kapferer, 2008). People rather buy products or make use of services of an organisation that has 'a good name' and is well known, than an organisation they do not know or that has a bad reputation. Reputation is a sort of capital which is manageable and measurable, and it is part of the market value of the firm (Fombrun, 2002; Nyárády and Szeles, 2004). Consequently, corporate image management is to achieve a favourable image and reputation which leads to competitive advantage or "strategic advantage". Balmer (2005) asserts that a strong and favourable corporate image offers an organisational number of distinct benefits. Corporate image management is of crucial importance for an organisation that strives to achieve success. By clear and structured management, organisations are able to create an adaptable corporate identity, which means an identity that can manage to survive the environmental changes that have been going on in the past decades (Balmer \& Gray, 2000). Apparently, corporate image is not just a discriminating factor in a progressively rising market competition, it enables consistency in consumer demand, value addition of product and services, higher financial margins or profitability, greater market visibility as well as attraction of high-quality personnel to the organization.

In the global and local markets, the necessity of adding value to products or services is being constantly emphasized, thus, building a positive corporate image is definitely an asset. However, unethical practices such as environmental pollution, the offering of substandard products, poor qualitative services, poor involvement in corporate social responsibilities, giving of misguiding information, profiteering as well as dishonest services are some of the misconducts that can devalue organisations' image. These sharp practices have caused the customers to develop a negative image about manufacturing firms which on the long run affects the operations of these organizations, resulting in a high turnover of staff, low productivity, low patronage, reduced profitability and reduced interest of stakeholders. These issues trigger the following research questions: i. What is the effect of corporate social responsibility on organisations' productivity? ii. What effect has corporate reputation on organizations' growth? iii What is the effect of product differentiation on competitive advantage? Therefore, this study focuses on image management and competitive advantage of manufacturing firms in Southeast, Nigeria 


\subsection{Literature Review}

\subsection{Corporate Social Responsibility (CSR) and Organisations' Productivity}

Holme and Watts (2000) define corporate Social Responsibility (CSR) as the continuing commitment by businesses to behave ethically in business processes and contributes to socio-economic development while furthering the quality of life of the employees as well as the local or host community and the society at large. Corporate Social Responsibility simply refers to the obligations of companies to society, more specifically, obligations to stakeholders and those who influence corporate policies and practices (Khanifar, Nazari, Emami \& Soltani, 2012). Companies participate in CSR in order to look better, feel better, do better and live longer (Kotler \& Lee, 2005). These explanations imply that, by participating in CSR, firms, companies or organisations will look good in the view of potential customers, business colleagues, investors as well as the media.

While some researchers state that CSR improves the brand, others believe that organisations with a strong reputation for CSR will last longer. For instance, Chakraborty (2010) affirms that CSR performs its role as an internally embedded and self-regulating policy that help firms evaluate and maintain adherence to the law, ethical benchmarks or standards as well as international best practices. However, Moon (2011), posits that businesses are motivated to engage in CSR from self-preservation perspective, thus, superficial altruism. According to Forbes (2010), corporate social responsibility works in two ways, hence, the company gives back to society in turn while the people or consumers get to know about the company who helped them most and cater to their products and services - a symbiotic relationship. The practice of CSR is not uniform among all business entities but its objective of giving back to society is resonated across the various models employed by organisations. Consequently, Assadourian (2006) affirms that businesses have begun to accord high value and importance to responsible behaviour.

Corporate social responsibility initiatives have the potentials to benefit firms and organisations by enabling conditions which can raise the commitment and motivation of employees to become increasingly productive. On the other hand, it can also motivate the society and enhance patronage. Firms that engage in CSR activities tend to be more successful than those that fail to employ the tools and perspectives to enhance employee and consumer commitment. The benefits of these engagements cut across employee retention, better opportunities in recruitments, cost reduction, reduction of absenteeism, better skill development and of course motivation for continuous learning and self-development. Kramer and Porter (2006) describe the reasons for participating in CSR as including - moral obligation for businesses, desire for sustainability, need for license for continued operation, and value of reputation for any business outfit.

Most importantly, Kotler \& Lee (2005) have an explicit economic view of the reason/s why companies participate in CSR described as -increased sales and market share, brand image and positive feeling from customers, enhanced image and clout (positive publications from business reports and magazines), improved brand positioning, increased ability to attract, motivate and retain employees, decreased operation costs and, increased interest for investors and financial analysts.

Methaq (2016) established that CSR promotes performance. Similarly, Bernstein (2008) posits that corporate social responsibility significantly enhances employee performance. Thus, the following hypothesis is presented $\mathrm{H}_{1}$ : Corporate social responsibility positively affects organisations' productivity.

\subsection{Corporate Reputation and Organizations' Growth}

Reputation is the reflection of an organisation over time as seen through the eyes of its stakeholders (Saxton, 1998). Reputation is a stakeholder's overall evaluation of a company over time (Gotsi \& Wilson, 2001). According to Bensiali (2011), corporate reputation is based on intangible aspects of an organisation's performance, culture, marketing and quality of products and services and takes time to spread. Basdeo, Smith, Grimm, Rindova \& Derfus (2006), explained that reputation formation is a communication process in which industry context and actions of rivals influence how signals of focal firms affect its reputation. Since reputation is an intangible asset, external constituents may not fully observe the activities that may lead them to form the impression of a firm. Reputation is formed on perceptions, that it is an aggregate perception of all stakeholders, and that it combines a firm's past actions, current state, and prospects (Walker, 2010).

Moreover, there could be threats to a firm if it does not pay attention to build its reputation. The threats include bad behavior by executives, unsafe or defective products, customer complaints, employee 
complaints, poor treatment of employees, poor handling of layoffs and/or termination (Burke, 2011). Notably, consumers have a low opinion of organisations especially in developing countries (Nigeria inclusive). In addition, there are more threats to a company's reputation today than previously (Burke, 2011).

Thus, corporate reputation is becoming more and more important in Nigeria where there is even more competition, poor product differentiation strategies, and pricing concerns in the service sector. Thus, building a highly regarded corporate reputation or corporate brand had become even more important.

Paul \& James (2014) affirm that corporate reputation significantly affects organisational productivity. Also, Burke (2011) established that corporate reputation increases company's sales and profit. Thus, the second hypothesis is proposed $-\mathrm{H}_{2}$ : Corporate reputation has a positive effect on organisations' growth.

\subsection{Product Differentiation and Strategic Advantage}

Product differentiation is a category of the two kinds of competitive advantage that may be available to a firm. Porter (1980) states that cost advantage and differentiation are the two strengths of a firm which can be applied in either broad or narrow scopes resulting in three generic strategies i.e. cost leadership, differentiation, and focus strategies. An organisation can differentiate itself from its competitors if it can offer something that is unique and valuable to its customers. Differentiation is about creating uniqueness and the principal uniqueness drivers according to Porter's viewpoint include policy choices, supplier and value chain linkages, timing, location, interrelationships, learning and spillovers, integration, scale, and institutional factors.

Cole (2008) posits that potential strategies for product or service differentiation include: product features and benefits, location(s), staff, operating procedures, price, customer incentive programs, guarantees and warranties, brand name recognition, goodwill, value-added products/services, extended growing/ operating season, soils, buildings, location, and landscape, water, access to irrigation and wetlands, weather, plants and animals, organisation and alliances, customer experience and quality. Deductively, a venture's most effective differentiation is the one that will bring the venture the greatest advantage. Porter (1990) affirms that it is important for a firm to differentiate itself among more than one dimension in order to reach the desired results

One way of achieving competitive advantage is through competency-based approaches in which an organisation tries to build differentiation as its core competence, which if peculiar to the organisation will be difficult for competitors to imitate. These strategies have a long-term benefit to the organisation especially if they are not easily duplicated. Differentiation builds competitive advantage by making customers more loyal, less price sensitive and less willing to consider other product alternatives (Johnson \& Scholes, 2002). According to Rao (2011), the firm pursuing a high differentiation strategy along some key product's attribute or buyer need, can earmark its own strategic group within the industry in such a scenario, destructive price war can be avoided. Product quality helps the firm build its own reputation and demand that often gets translated into higher market share as well differentiation arises, and competition increasingly occurs on the bases of product improvements. This also causes the marketer to look at the user's preferences, the use's mode or choice of purchase and usage of products (consumption system or pattern), as well as related services. Each improvement adds cost, however, the improvement advantages soon become expected benefits and very crucial points of consideration in the process. For instance, today's hotel guests expect cable, satellite television with remote control and high-speed internet access or two phone lines, this means competitors must search for these other features and benefits (Jaquier, 2010).

As competition intensifies, product design offers a potential way to differentiate and position a company's products and services. Therefore, the rising prices, breakthroughs in technology and swiftpaced markets are not adequate! Product design or redesign may just be a factor that could offer a firm or an organisation its competitive advantage or edge over competitors. Design itself involves all the distinct characteristics or traits which affect the way a product appears, appeals, feels and fits its role (functions) with regards to customer needs. This aspect is exceptionally significant in the making and marketing goods and services. The designer must figure out how much to invest in form, feature development, performance, durability, reliability, reparability, and style (Jaquier, 2010). 
According to Kotler (2009), sellers may face abundance of differentiation possibilities including form, features, customization, performance quality, conformance quality, durability, reliability, reparability and style and when a physical product cannot easily be differentiated, the key to competition success may lie in adding valued services and improving their quality. The main service differentiation is ordering, ease delivery, installation, customer training, customer consulting, maintenance and repair. Noticeably, when customers perceive a product or service as better than the rest offered, they become more willing to pay a premium price relative to the price they will pay for competing offerings. Ade (2012) posits that the firm's ability to maintain rivals to imitate and outperform. Thus, sustainable competitive advantage that differentiates a firm from its rivals has become an intangible asset along with corporate image.

Stuart (2010) posits that product differentiation increases a company's profitability. Balmer and Gray (2000) established that product differentiation encourages and project a good company image. Accordingly, the third hypothesis is presented. $H_{3}$. Product differentiation positively affects strategic advantage.

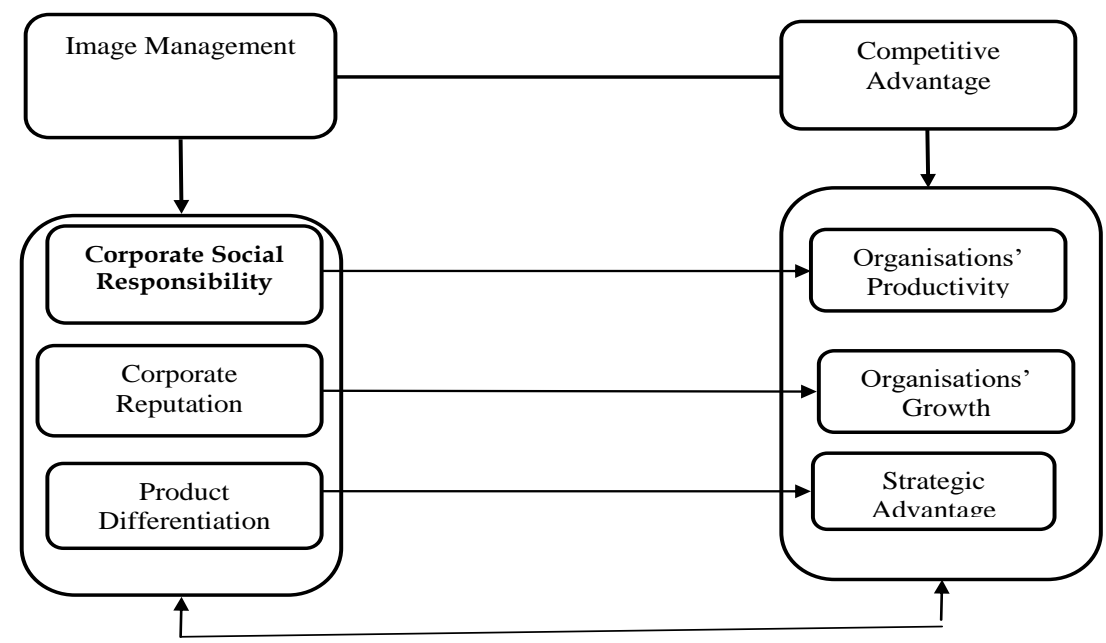

Fig 2.1 Conceptual Model of Image Management and Competitive Advantage

\section{Previous Work}

Okocha, Otika and Osuagwu (2019) conducted a study on the relationship between corporate image and competitive advantage in Mobile Telecommunication Industry in Nigeria. The objectives were to ascertain the relationship between corporate image and firm's competitive advantage, determine the relationship between corporate identity and the firm's competitive advantage, and assess the relationship between corporate reputation and competitive advantage. The cross-sectional survey design was adopted. Spearman rank correlation coefficient analytical tool was used for hypotheses testing. The results revealed that there was a significant relationship between corporate image and firm's competitive advantage, there was a strong relationship between corporate reputation and competitive advantage, and there was also a significant relationship between corporate identity and the firm's competitive advantage. The study concluded that corporate image provides access to customer satisfaction and loyalty.

\section{Research Methodology}

The study adopted the survey design. The survey involves the use of questionnaire that is administered to a sample. The questionnaire was structured on five-point Likert scale format. Secondary data were collected from books, journals, and internet sources. The target population consists of 9038 employees of junior and senior category of the manufacturing firms in southeast, Nigeria. A sample size of 563 was derived using Cochran's formula at 5\% error tolerance and 95\% level of confidence. The validation of the instrument was undertaken by five experts, three from the academia and two from the industry. The test- retest was carried out for reliability test and thereafter subjected to test with Spearman rank order correlation technique which yielded a correlation coefficient of 0.83 indicating a high degree of items consistency. Out of 563 copies of the questionnaire that were distributed, 506 copies representing 
$(89.88 \%)$ were returned while 57 copies representing $(10.12 \%)$ were not returned. The hypotheses were tested with ordinal logistic regression on Statistical Package for Social Sciences (SPSS, version 20.0) software. Ordinal logistic regression was suitable for testing the hypotheses because of the use of questionnaire that provides ordinal data which represent people's opinion, and which cannot be predicted.

Table 1: Analyses of Respondents' Responses

\begin{tabular}{|c|c|c|c|c|c|c|c|}
\hline $\mathbf{S} / \mathbf{N}$ & Options & $\mathbf{A}$ & SA & D & SD & $\mathbf{U}$ & Total \\
\hline 1 & $\begin{array}{l}\text { To determine the effect of corporate social responsibility } \\
\text { on organisations' productivity. }\end{array}$ & & & & & & \\
\hline$\overline{\mathrm{i}}$ & $\begin{array}{l}\text { Organisations' productivity could be enhanced by } \\
\text { corporate social responsibility }\end{array}$ & 100 & 387 & 10 & 5 & 4 & 506 \\
\hline Ii & $\begin{array}{l}\text { Corporate social responsibility can attract community } \\
\text { support which encourages productivity in the organisation }\end{array}$ & 200 & 276 & 20 & 7 & 3 & 506 \\
\hline Iii & $\begin{array}{l}\text { Customers patronise companies that carry out their } \\
\text { corporate social responsibility and hence increase their } \\
\text { profitability }\end{array}$ & 191 & 300 & 10 & 4 & 1 & 506 \\
\hline \multirow[t]{2}{*}{ iv } & $\begin{array}{l}\text { Corporate social responsibility can improve better life and } \\
\text { standard of living within the community which patronise } \\
\text { companies' products }\end{array}$ & 200 & 301 & 3 & 2 & 0 & 506 \\
\hline & Grand Total/ Percentage & \multicolumn{2}{|c|}{ 1955(96.59) } & \multicolumn{2}{|c|}{$61(3.01 \%)$} & $8(0.40 \%)$ & 2,024 \\
\hline 2 & $\begin{array}{l}\text { To assess the effect of corporate reputation on } \\
\text { organisations' growth. }\end{array}$ & $\mathbf{A}$ & SA & $\mathbf{D}$ & SD & $\mathbf{U}$ & Total \\
\hline$\overline{\mathrm{i}}$ & Corporate reputation can affect organisations' growth & 404 & 75 & 20 & 4 & 3 & 506 \\
\hline Ii & $\begin{array}{l}\text { Good workplace environment can improve firms' } \\
\text { productivity }\end{array}$ & 300 & 166 & 21 & 10 & 9 & 506 \\
\hline Iii & Adherence to ethical standards boosts profitability & 45 & 447 & 9 & 2 & 3 & 506 \\
\hline \multirow[t]{2}{*}{ iv } & $\begin{array}{l}\text { Good product and consumer relations enhance } \\
\text { productivity }\end{array}$ & 12 & 490 & 2 & 1 & 1 & 506 \\
\hline & Grand Total/ Percentage & \multicolumn{2}{|c|}{$1939(95.80 \%)$} & \multicolumn{2}{|c|}{$69(3.41 \%)$} & $16(0.79 \%)$ & 2,024 \\
\hline 3 & $\begin{array}{l}\text { To ascertain the effect of product differentiation on } \\
\text { strategic advantage. }\end{array}$ & $\mathbf{A}$ & SA & D & SD & $\mathbf{U}$ & Total \\
\hline $\mathrm{i}$ & $\begin{array}{l}\text { Product differentiation procures strategic advantage on } \\
\text { the firms. }\end{array}$ & 310 & 134 & 27 & 30 & 5 & 506 \\
\hline Ii & High product quality enhances competitive edge & 400 & 95 & 7 & 4 & 0 & 506 \\
\hline Iii & $\begin{array}{l}\text { Improved design of products maximizes competitive } \\
\text { advantage }\end{array}$ & 94 & 392 & 11 & 6 & 3 & 506 \\
\hline \multirow[t]{2}{*}{ iv } & $\begin{array}{l}\text { Product innovation and unique product enhance sales } \\
\text { growth }\end{array}$ & 400 & 93 & 6 & 2 & 5 & 506 \\
\hline & Grand Total/ Percentage & \multicolumn{2}{|c|}{$1918(94.763 \%)$} & \multicolumn{2}{|c|}{$93(4.595 \%)$} & $13(0.642 \%)$ & 2,024 \\
\hline
\end{tabular}

Source: Field Survey, 2019.

\section{Analyses of Results}

$\mathbf{H}_{1}$ : Corporate social responsibility positively affects organisations' productivity.

The responses obtained from the questions asked to determine the effect of corporate social responsibility on organisations' productivity reveals that 1,955 $(96.59 \%)$ of the respondents agree that corporate social responsibility affects organisations' productivity. Thus, 61 (3.01\%) of the respondents disagree while $8(0.40 \%)$ of the respondents are undecided. 
Journal of Business and Retail Management Research (JBRMR), Vol. 14 Issue 2

Table 2: Parameter Estimate from ordinal logistic regression test for hypothesis (1)

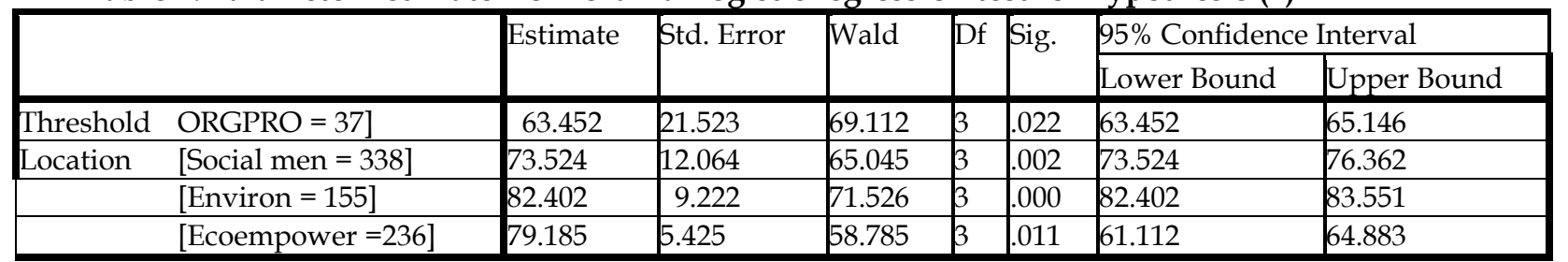

Link function: Logit.

The result in Table 2 reveals that corporate social responsibility positively affects organisations' productivity. With an increase in the probability of increased productivity at the odds ratio of $63.452(95 \%$ CI, 63.452 to 65.146), Wald $\chi^{2}(1)=69.112, p=0.022<0.05$. Therefore, the alternative hypothesis which states that corporate social responsibility positively affects organisations' productivity is hereby accepted and the null hypothesis is rejected.

\section{$\mathrm{H}_{2}$ : Corporate reputation has a positive effect on organisations' growth.}

The responses derived from the questions asked to ascertain the effect of corporate reputation on organisations' growth indicates that $1939(95.80 \%)$ of the respondents agree that corporate reputation affects organisations' growth. Thus, $69(3.41 \%)$ of the respondents disagree while $16(0.79 \%)$ of the respondents are undecided.

Table 3: Parameter Estimate from ordinal logistic regression test for hypothesis (2)

\begin{tabular}{|c|c|c|c|c|c|c|c|c|}
\hline & \multirow[t]{2}{*}{ Estimate } & \multirow[t]{2}{*}{ Std. Error } & \multirow[t]{2}{*}{ Wald } & \multirow[t]{2}{*}{ df } & \multirow[t]{2}{*}{ Sig. } & \multicolumn{2}{|c|}{$95 \%$ Confidence Interval } \\
\hline & & & & & & & Lower Bound & Upper Bound \\
\hline Threshold & [FMGROWTH = 172] & 56.018 & 5.203 & 62.837 & 1 & .024 & 56.018 & 60.567 \\
\hline Location & {$[$ Corprep $=429]$} & 69.171 & 22.650 & 74.010 & 1 & .007 & 69.171 & 72.909 \\
\hline
\end{tabular}

Link function: Logit.

The result in Table 3 reveals that corporate reputation has a positive effect on organisations 'growth. With an increase in the probability of increased growth at the odds ratio of 69.171 (95\% CI, 69.171 to 72.909), Wald $X^{2}(1)=74.010, p=0.007<0.05$. Therefore, the alternative hypothesis which states that corporate reputation has a positive effect on organizations' growth is hereby accepted and the null hypothesis is rejected.

\section{$\mathrm{H}_{3}$. Product differentiation positively affects strategic advantage.}

The responses obtained from the questions asked to determine the effect of product differentiation on strategic advantage reveals that 1,918 (94.763\%) of the respondents agree that product differentiation affects strategic advantage. Thus, $93(4.595 \%)$ of the respondents disagree while $13(0.642 \%)$ of the respondents are undecided.

Table 4: Parameter Estimate from ordinal logistic regression test for hypothesis (3)

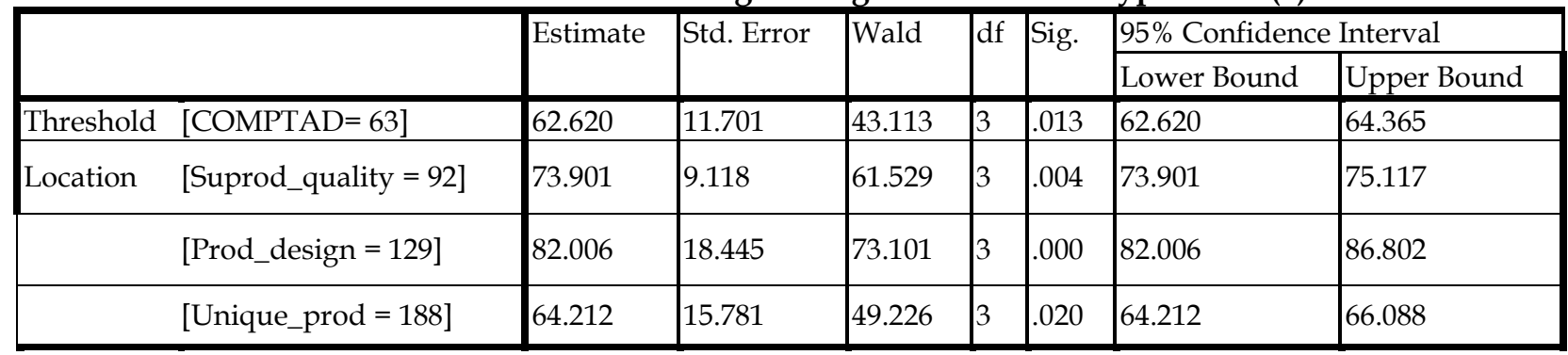

Link function: Logit.

The parameter estimates in table (4) reveals that product differentiation positively affects strategic advantage. With an increase in the probability of increased advantage at the odds ratio of 62.620 (95\% CI, 62.620 to 64.365$)$, Wald $\chi^{2}(1)=43.113, p=0.013<0.05$. Therefore, the alternative hypothesis which states 
that product differentiation positively affects strategic advantage is hereby accepted and the null hypothesis is rejected.

\section{Discussion of Results}

According to our first objective which examined the effect of corporate social responsibility on organisations' productivity, the result from the ordinal logistic regression revealed that corporate social responsibility positively affected organisations' productivity $(\beta=63.452, \mathrm{p}=0.022<0.05)$. Thus, the alternative hypothesis which states that corporate social responsibility positively affects organisations' productivity was accepted and the null hypothesis was rejected. This indicates that sustained corporate social responsibility is pivotal to optimal productivity in organisations. Methaq (2016) established that corporate social responsibility promotes performance. Bernstein (2008) posits that corporate social responsibility significantly enhances employee performance.

Moreover, the study also ascertained the effect of corporate reputation on organisations' growth which is our second objective. The result revealed that corporate reputation had a positive effect on organisations' growth $(\beta=69.171, p=0.007<0.05)$. This implies that corporate reputation plays an integral role in the growth of organisations. Paul \& James (2014) affirmed that corporate reputation significantly affects organisational productivity. Burke (2011) states that corporate reputation increases company's sales and profit.

Finally, the study examined the effect of product differentiation on strategic advantage. The result from the ordinal logistic regression test revealed that product differentiation positively affected strategic advantage $(\beta=62.620, p=0.013<0.05)$. Therefore, the alternative hypothesis which states that product differentiation positively affects strategic advantage was accepted and the null hypothesis was rejected. This finding relates to the fact that organisations could procure strategic advantage by leveraging on the many beneficial dimensions of product differentiation such as product innovation and improved product design. Stuart, (2010) posits that product differentiation increases a company's profitability. Balmer and Gray (2000) established that product differentiation enhances the image of a company.

\section{Conclusion}

Corporate image management is an essential key for obtaining and maintaining public trust. It involves actions taken with the intention to create, maintain, and gain public trust. Every organisation has its own image when it is properly developed and managed, could reflect in the firm's level of commitment to quality, excellence and good relationship with its stakeholders including current and potential customers, present employees and future employees, competitors and investors, governing bodies and the general public at large. Corporate image is a tool which an organisation uses in gaining strategic advantage. Companies that are successful, invest heavily in creating sustainable competitive advantage as it is the single most dependent contributor that gives an above-average level of profitability.

\section{Recommendations}

The study proffers the following recommendations

i. Manufacturing firms should carry out corporate social responsibility so as to engender public trust, which in the long run will increase customers' patronages and profitability of the firms.

ii. Manufacturing firms should create a corporate reputation that will attract customers to patronize their products with the belief that the products have superior quality.

iii. Manufacturing firms should adopt product differentiation as a competitive strategy for winning customers over from rivals in the market.

\section{Limitations}

The study had a limitation for having not explored the following relevant topics: goodwill, corporate window dressing and the danger of 'Greenwashing' organisation living off old reputation, and the role of confirmation bias. Future researchers should explore the listed topics in researches on corporate reputation and organisation's growth, product differentiation and strategic advantage.

\section{References}

Ade, O. (2012). Strategic Agility and Competitive Performance in Nigerian Telecommunication Industry: An Empirical Investigation, American International Journal of Contemporary Research, 2(3) 227 - 238. 
Assadourian, E. (2006). The State of Corporate Responsibility and the Environment. International Environmental Law Review, 18 (4) 7.

Balmer, J. M. T. \& Gray, E. R. (2000) Corporate Identity and Corporate Communications: Creating a Competitive Advantage, Industrial and Commercial Training 32 (7) 256.

Balmer, J. M. T. \& Gray, E. R. (2003). Corporate Brands: What are They? What of Them? European Journal of Marketing, 37 (7) $972-997$.

Balmer, J. M. T. (1998). Corporate Identity and the Advent of Corporate Marketing. Journal of Marketing Management, 14 (8) $963-996$.

Balmer, J. M. T. (2005). Corporate Brands: A Strategic Management Perspective, Working Paper Series, 05/43, pp. $2-22$.

Balmer, J. M. T. \& Greyser, S. A. (2003). Revealing the Corporation: Perspectives on Identity, Image, Reputation, Corporate Branding, and Corporate-level Marketing, London: Routledge.

Basdeo, D.K., Smith, K. G., Grimm, C. M., Rindova, V. \& Derfus, P. (2006). The Impact of Market Actions of Firm Reputation. Strategic Management Journal, 27, 1205-1219.

Bensiali, A. K. (2011). How to Measure and Manage Corporate Reputation.

Bernstein, D. (2008). Corporate Image and Reality: A Critique of Corporate Communications. East Bourne: Holt, Rinehart and Winston Ltd.

Burke, R. J. (2011). Corporate Reputations: Development, Maintenance, Change, and Repair. In: Burke, R., Martin, G. and Cooper, C.L. (eds) Corporate Reputation: Managing Opportunities and Threats. London: Ashgate Publishing.

Chakraborty, S. (2010). Corporate Social Responsibility and Society: Unpublished.

Christensen, L. T., and Askegaard, S. (2001). Corporate Identity and Corporate Image Revisited. A Semiotic Perspective, European Journal of Marketing, 35(3/4), 292-315.

Cole, E. (2008). Strategies for Competitive Advantage: Technical Report, Department of Agricultural and Applied Economics, University of Wyoming.

Cole, M (2005). Emerging Forms of Competitive Advantage: Implications for Agricultural Producers, Midwest Agribusiness Trade Research and Information Center Research Paper- 03-MRP 5.

Fombrun, C. (2002). Reputation, Realizing Value from the Corporate Image, New York: Harvard Business School Press.

Forbes, (2008). Company Social Responsibility becomes a Way of Life for Employees. Forbes Blog. Retrieved November 2018 from http://blogs.forbes.com/csr/.

Forbes, (2010). Forbes Blog. Retrieved January 2019 from http://blogs.forbes.com/csr/.

Gotsi, M., \& Wilson, A. M. (2001). Corporate Reputation: Seeking a Definition. Corporate Communications: An International Journal, 6(1), 24-30.

Gregory, J. R. \& Wiechman, J. G. (2010). Marketing Corporate Image; Chicago: NTC Business Books.

Hatch, M. J., Schultz, M., \& Williamson, J. (2003). Bringing the Corporation into Corporate Branding, European Journal of Marketing, 37(7/8), 41-64.

Hatch, M., J \& Schultz, M. (2004). Organizational identity: A Reader, Oxford University Press.

Holme, R., \& Watts, P. (2000). Corporate Social Responsibility: Making Good Business Sense. Oxford: World Business Council for Sustainable Development.

Jaquier, B. (2010). Differentiation strategy Accessed 13.2.2019. http://www.ecofine.com/strategy/Differenciation \%20 stategy.htm.

Johnson G. \& Scholes K. (2002). Exploring Corporate Strategy; Hertfordshire: Prentice Hall International,

Kapferer, J. N. (2008). Strategic Brand Management: Creating and Sustaining Brand Equity Long Term. Auflage, London.

Khalifa, H. Nazari, K. Emmi, M. \& Sultana, H. (2012). Impacts of Corporate Social Responsibility Activities on Company Financial Performance; Interdisciplinary Journal of Contemporary Research in Business 3 (9).

Kotler, P. (2009). Marketing Management; New Jersey: Prentice-Hall International.

Kotler, P. \& Lee, N. (2005). Corporate Social Responsibility: Doing the Most Good for your Company and your Cause. Hoboken, New Jersey: John Wiley \& Sons, Inc.

Kramer, M. R. \& Porter, M. E. (2006). Strategy and Society: The Link between Competitive Advantage and Corporate Social Responsibility. Harvard Business Review, 84(12), 78-92.

Melewar, T. C. \& Saunders, T. (2000). Corporate Identity in the Service Sector; Public Relations Quarterly, 46(2), 20-26.

Methaq, A.S. (2016). An Investigation of Corporate Image Effect on Word of Mouth (WOM): The Role of Customer Satisfaction and Trust; International Journal of Business Administration, 7(3) 9.

Moon, J. (2011). Corporations and Citizenship, Cambridge: Cambridge University Press.

Nyárády, G., \& Szeles, P. (2004). Public Relations-II, Perfekt, Budapest.

Okocha, E. R., Otika, U. S., \& Osuagwu, B. O. (2019). Relationship between Corporate Image and Competitive Advantage in Mobile Telecommunication Industry in Nigeria; European Journal of Innovation Business Management, Vol. 3.

Olins, W. (2005). Corporate Identity. London: Thames and Hudson.

Paul, M.\& James, M. (2014). Relationship between Corporate Image and Customer Loyalty in the Mobile Telecommunication Market in Kenya: Management Studies, 2 (5) 299 -308. 
Porter, M (1996). Competitive Advantage, Agglomeration Economies, and Regional Policy; International Regional Science Review, 19 (1-2) 85 - 90.

Porter, M. E. (1980). Competitive strategy: techniques for analyzing industries and competitors. New York: Free Press.

Porter, M.E. (1990). The Competitive Advantage of Nations, New York: Free Press.

Rao, V. S. (2011). Strategic Business Management, Durban: Excel Learning Pty. Ltd Durban South Africa.

Saxton, M.K. (1998). Where does Reputation come from? Corporate Reputation Review, 1 (4), 393-399.

Stuart, H. (2010). Towards a Definitive Model of the Corporate Identity Management Process; An International Journal of Management, 4(32), $200-207$.

Topalian, A. (2003). Experienced Reality: The Development of Corporate Identity in the Digital Era; European Journal of Marketing, 37(7/8), 1119 - 1132.

Walker, K. (2010) A Systematic Review of Corporate Reputation Literature: Definition, Measurement, and Theory, Corporate Reputation Review: 12(4) 357-387. 